Journal of Southeast Asian

\title{
Three Poems: Charges Against a Newborn; Unanswered; For the First Generation
}

Mai N. Do

Washington College, donguyenmai@gmail.com

Follow this and additional works at: https://docs.lib.purdue.edu/jsaaea

Part of the Bilingual, Multilingual, and Multicultural Education Commons

\section{Recommended Citation}

Do, Mai N. (2019) "Three Poems: Charges Against a Newborn; Unanswered; For the First Generation," Journal of Southeast Asian American Education and Advancement. Vol. 14 : Iss. 1, Article 3. DOI: $10.7771 / 2153-8999.1183$

Available at: https://docs.lib.purdue.edu/jsaaea/vol14/iss1/3

This document has been made available through Purdue e-Pubs, a service of the Purdue University Libraries. Please contact epubs@purdue.edu for additional information.

This is an Open Access journal. This means that it uses a funding model that does not charge readers or their institutions for access. Readers may freely read, download, copy, distribute, print, search, or link to the full texts of articles. This journal is covered under the CC BY-NC-ND license. 


\title{
JSAAEA Journal of Southeast Asian American
Education and Advancement
}

Vol. 14 Iss. 1 (2019)

\author{
Www.JSAAEA.org
}

\section{Creative and Literary Works}

\author{
Three Poems
}

Do Nguyen Mai

\section{Charges Against a Newborn}

How guiltless an infant, before she

Starved an entire nation.

Snapped soldiers' ribcages open into blossoms of dust in the light.

Razed ten thousand acres of heartbeat.

Gutted a bloodline.

Buried her grandmother in a hospital room like it wasn't already lined with white.

Scorched her grandfather's limp corpse until roots ran unhindered through his skin.

Taught her mother the sound of bullet to spine.

Cried out her first breath.

\footnotetext{
(C)

SDIERIGHISRESEREEDReaders are free to copy, display, and distribute this article, as long as the work is attributed to the author(s) and the Journal of Southeast Asian American Education \& Advancement, it is distributed for non-commercial purposes only, and no alteration or transformation is made in the work. More details of this Creative Commons license are available at http://creativecommons.org/licenses/by-nc-nd/3.0/. All other uses must be approved by the author(s) or JSAAEA. Journal of Southeast Asian American Education \& Advancement, Vol. 14. Iss. 1. (2019) ISSN: 2153-8999
} 


\section{Unanswered \\ After Joshua Nguyen}

Em ơi,

don't look back

when my spine snaps

against the cold click

of the trigger,

when my lungs flood

with the fullness

of the night sky,

when my body drops

headfirst

when the ocean folds

its palms over my chest,

when my ribcage whistles

with the waking shore,

when the water ripples,

when the boat tips over,

when I become the sea

swelling beneath your swaying ship -

em oi,

I will carry you

to shore. 


\section{For the First Generation}

We entered the world

$$
\begin{aligned}
& \text { gun - fire - work, } \\
& \text { metal, burning, bleeding. }
\end{aligned}
$$

we, born screaming keep our mouths shut (our mothers safe) we fear a fire bodies scorched

to quiet rage is to die without grave another corpse unnamed

we fear a fire

we, already alight

not the soot, but the ash:

rise, rise afraid, a blaze.

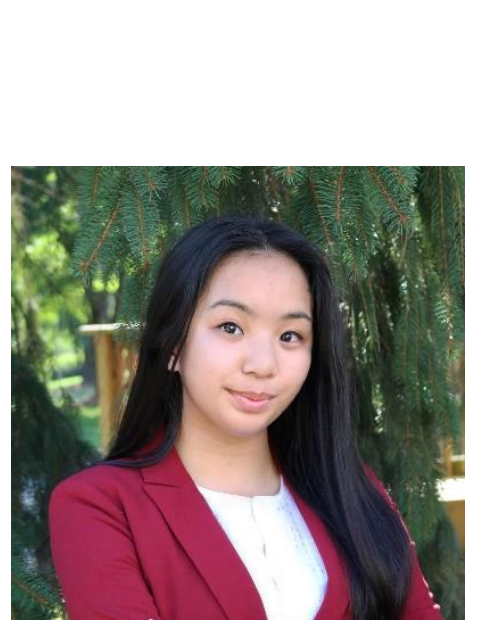

\section{About the Author}

Do Nguyen Mai, is a Vietnamese American poet and researcher from Santa Clarita, California. She completed her associate degrees in history and liberal arts and sciences at College of the Canyons, and she currently researches elections and policy for Courage Campaign. Among other awards and distinctions, Mai is a 2017 Frost Place Chapbook Contest Semi-Finalist, a 2017 Rose O'Neill Literary House Jacoby Endowment Grant recipient, a 2018 Goldstein Program in Public Affairs Experiential Learning Grant recipient, and a Junior Chamber International Santa Clarita Valley 40 Under 40 Class of 2018 honoree. Her first book, Ghosts Still Walking, is available from Platypus Press and her second book, Battlefield Blooming, is forthcoming from Sahtu Press in spring of 2019. 


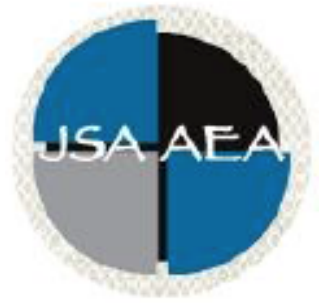

Vol.14 Iss.1 (2019)

\title{
Journal of Southeast Asian American Education and Advancement
}

\author{
www.JSAAEA.org
}

\section{Editor}

Dr. Wayne E. Wright

Purdue University

Associate Editors

Dr. Chhany Sak-Humphry

University of Hawaii at Manoa

Dr. Phitsamay Sychitkokhong Uy

University of Massachusetts, Lowell

\author{
Book Review Editor \\ Dr. Vichet Chhuon \\ University of Minnesota \\ Creative Works Editor \\ Bryan Thao Worra \\ Lao Assistance Center \\ Journal Manager \\ Fang Gao \\ Purdue University
}

\section{Editorial Review Board}

Dr. Steve Arounsack

California State University, Stanislaus

Dr. Sovicheth Boun

Salem State University

Dr. Virak Chan

Purdue University
Dr. Carl L. Bankston III

Tulane University

Dr. Phala Chea

Lowell Public Schools

Dr. George Chigas

University of Massachusetts, Lowell 


\author{
Dr. Loan Dao \\ University of Massachusetts Boston \\ Dr. Changming Duan \\ University of Missouri-Kansas City \\ Dr. Sothy Eng \\ Lehigh University \\ Dr. Vincent K. Her \\ University of Wisconsin, Eau Claire \\ Dr. Peter Nien-Chu Kiang \\ University of Massachusetts, Boston \\ Dr. Kevin K. Kumashiro \\ University of Illinois, Chicago \\ Dr. Ha Lam \\ Eastern Mennonite University \\ Dr. Jonathan H. X. Lee \\ San Francisco State University \\ Dr. Monirith Ly \\ Royal University of Phnom Penh \\ Dr. Bic Ngo \\ University of Minnesota \\ Dr. Leakhena Nou \\ California State University, Long Beach \\ Dr. Mark Pfeifer \\ SUNY Institute of Technology \\ Dr. Loan T. Phan \\ University of New Hampshire \\ Dr. Karen Quintiliani \\ California State University, Long Beach \\ Dr. Angela Reyes \\ Hunter College \\ The City University of New York \\ Dr. Fay Shin \\ California State University, Long Beach \\ Dr. Christine Su \\ College of San Mateo \\ Dr. Alisia Tran \\ Arizona State University \\ Dr. Khatharya Um \\ University of California, Berkeley \\ Dr. Kim Tran \\ University of California, Los Angeles, \\ Glendale Community College \\ Dr. Molly Wiebie \\ The University of Texas at Austin
}

Dr. Hien Duc Do

San Jose State University

Dr. Sophal Ear

Occidental College

Dr. Jeremy Hein

University of Wisconsin, Eau Claire

Dr. Nancy H. Hornberger

University of Pennsylvania

Dr. Peter Tan Keo

New York University

Dr. Yvonne Kwan

San Jose State University

Dr. Ravy Lao

California State University, Los Angeles

Dr. Stacey Lee

University of Wisconsin, Madison

Dr. Sue Needham

California State University, Dominguez Hills

Dr. Max Niedzwiecki

Daylight Consulting Group

Dr. Clara Park

California State University, Northridge

Dr. Giang Pham

University of Massachusetts Amherst

Dr. Malaphone Phommasa

University of Clifornia Santa Barbara

Dr. Kalyani Rai

University of Wisconsin-Milwaukee

Dr. Cathy J. Schlund-Vials

University of Connecticut, Storrs

Dr. Nancy J. Smith-Hefner

Boston University

Dr. Yer J. Thao

Portland State University

Dr. Monica M. Trieu

Purdue University

Dr. Silvy Un

Saint Paul Public Schools

Dr. Linda Trinh Vo

University of California, Irvine

Dr. Yang Sao Xiong

The University of Wisconsin-Madison

Dr. Zha Blong Xiong

University of Minnesota 


\section{Doctoral Student Editorial Review Board}

\author{
Linh Dang \\ University of Rochester \\ My-Lan Huynh \\ California State University East Bay \\ Hoa Nha Nguyen \\ Boston College \\ Thien-Huong Ninh \\ University of Southern California \\ Krissyvan Truong \\ Claremont Graduate University \\ Melissa Vang \\ San Diego State University \\ Claremont Graduate University
}

\author{
Annie BichLoan Duong \\ San Joaquin County Office of Education \\ Dung Minh Mao \\ University of Minnesota \\ Khoi Nguyen \\ George Mason University \\ Linda Marie Pheng \\ University of Wisconsin-Madison \\ Mai Vang \\ University of Massachusetts Boston \\ Soua Xiong \\ San Diego State University \\ Claremont Graduate University
}

